\title{
THE VOLUNTEER MOVEMENT AT GRAAFF REINET (1856-1882)
}

The history of Graaff Reinet provides the earliest examples of civil defence in South Africa, for it was here that the early settlers established the commando system in the 1st, 2nd and 3rd Frontier Wars [1779-81, 1793 and 1799-1803]. Subsequently in the 4th, 5th, 6th and 7th Frontier Wars, the pattern of civil defence changed considerably when the burghers joined with Imperial forces. Significantly too, but it was a Graaff Reinetter who led the Voortrekkers to victory in 1838 at the Battle of Blood River. However, after 1850 the spirit of militarism was dying a natural death.

While frontier towns such as Grahamstown and King William's Town gave military security top priority, Graaff Reinet, no longer a frontier outpost, embarked on a programme of economic and commercial expansion.

\section{The first period [1856 - 1866]}

The revival of the military spirit in Graaff Reinet came about when the Governor, Sir George Grey, receiving an urgent dispatch to send all the regular Imperial forces to India, passed legislation to establish a civil or burgher Volunteer Force in 1856. In other words, the defence of the Colony would henceforth be in the hands of its citizens.

On Thursday, 14th February, 1856, the Graaff Reinet Rifle [Infantry] and Mounted Rifle [Cavalry] Corps were established. These volunteers were referred to as "The Greys", so-called, because the Corps had permission from Sir George Grey to wear his crest as their badge. Only the Governor or any other constituted authority had the right to call the Volunteers out. From the outset, the local magistrate, who was their Commandant, displayed so little active interest, that in July 1860, the Volunteers requested Sir George Grey to become their Colonel-in-Chief. The Governor also approved of their Rules and Regulations, which were modelled on military rules applicable to Imperial Regiments, proof of the high status which the Volunteers enjoyed. The Corps had their own Committee, which met once a month, to discuss and impose fines for breaches of discipline.

Up to 1862 , the story of the Volunteers is extremely disappointing. In April 1860, it was decided to disbandon the Cavalry Corps, the main reason being economic, since the Volunteers, who were mostly townsmen [clerks. artisans, etc.] could not each afford to purchase a horse, the necessary accoutrements, fodder and still find time to train a cavalry mount. Thereafter there were two infantry companies which merged into one in February 1861. One of the means used to create additional interest and stimulation among the members, was the addition of a Brass Band in 1857, which attended all parades. In July 1860, the Volunteers engaged six ex-German Legionnaires for a period of twelve months to lead the Band. To meet this additional expenditure of $£ 252$, the Volunteers raised their subscriptions from $2 / 6$ to $5 /-$ per month, in addition to an entrance fee of $7 / 6$. Eighteen months later the Volunteers found that they could no longer afford this additional expense.

However, the "Grey's Own" fought for its survival, and by 1862, it was said that the "Graaff Reinet Corps had died out about a dozen times." Although there were about 150 effectives, instances are only too numerous where about four members attended a parade and irregular attendance always remained the greatest threat to the existence of the Corps. This decline in interest was also due to the fact that fire-arms were not available.

Despite requests to the Military Stores at Grahamstown, the Volunteers did not receive them. Although the Government supplied the ammunition, it was expected that the Volunteers should procure their own rifles. The result was that the widest variety of rifles made their appearance at parades, in effect rendering the Corps a totally inefficient flighting unit. To alleviate this position, the merchants Wimble and Caro imported, duty free, 
Enfield Rifles which cost about f5 each, including additional expense for shako, etc. In 1863, Parliament voted aid to the Volunteer Corps, and henceforth, accoutrements were supplied from the Military stores on payment of a fee of $15 / 6$. Furthermore each volunteer was to be issued with 100 ball-cartridges.

Without a standard rifle, this placed more emphasis on drill and parades, which the men disliked intensely. Even novelties in the form of "moonlight marches" [with refreshments supplied by a local benefactor] failed to attract a regular attendance. A third source of dissatisfaction was the intense rivalry between leading men for election as officers. [Officers and N.C.O.'s were elected by the men by a two-thirds majority]. Up to 1862 there were no less than eight senior officers who had assumed command at some time or other, and this could only have contributed to lowering the morale of the men. A fourth reason was that the men, had to provide their own uniforms, which proved to be a financial hardship. ${ }^{1}$ The fortunes of the Volunteers were certainly at their lowest ebb towards the end of 1862.

At the beginning of 1863, the Volunteers made an unusual, but wise choice in their selection of their senior officer. It is not known whether Professor James Gill, teacher of Classics at the Graaff Reinet College, had the physical attributes of a soldier, but he certainly inspired the Volunteers, and for the first time since its existence, the Rifle Corps suddenly came alive. Just how low the Corps had sunk, was revealed by Prof. Gill saying:

"When first I was asked to take the command, I confess I hardly thought it a compliment," and, "I had very strong doubts as to whether any good could be done with it."

One of Captain Gill's first tasks was to establish the reason why the young men displayed so little interest in the Volunteer movement. In searching for his answer, he rocked the foundation of Graaff Reinet society and commerce when he declared:

"Now I know the explanation - our young men have no time. In small dull towns like London, time is of no value - business is never very pressing. In another obscure place called Manchester, where a Saturday halfholiday has been an established institution for some years, merchants can well enough spare a few hours a week to their clerks, for a public object. But such places are not to be compared to Graaff Reinet. Here, time is so precious, business is so overwhelming, that our merchants cannot afford their clerks an hour or two per month, to say nothing of a weekly holiday."

The criticism of the money-making Graaff Reinet merchants is only too obvious, and Gill's speech had a marked re-action. In a Memorandum, dated 29th July, 1863, fourteen merchants pledged to close their stores at 12.00 o'clock on the first Tuesday in every month. In this way, the Volunteers were now able to attend parades. Furthermore, now that the men had a standard rifle, Captain Gill, by means of clever psychological strategy, turned this to superb advantage. In his first address to the Volunteers, Gill emphasised that although he regarded drill of secondary importance, he considered that "undisciplined, undrilled men are useless", and further that it was a Volunteer's first duty [apart from hitting the enemy], to take care of himself, and that he "cannot commit a greater military offence than to allow himself to be shot." Gill insisted that one-third of all funds should be allocated for shooting-practice in an effort to improve the marksmanship of the men. As he lived at Adendorp, he requested a piece of ground in the village which could be used as a rifle range and butt. As from April 1863, target practice was held every week. Moonlight marches became more popular, and Mr. Wright's Hotel at Adendorp became the favourite rendezvous, the men singing songs all the way there and back [approx. eight km from Graaff Reinet to Adendorp].

Captain Gill realised the necessity for social enjoyment, coupled with fellowship, and above all, that competition amongst the Volunteers was one of the best means of keeping the movement alive. During the next three years, he and Sergeant-Major Hurford [the Postmaster], organised some of the best bi-annual bisleys that Graaff Reinet had ever seen. Handsome prizes were awarded to the best marksmen, competition was open to all ranks, with one proviso - that only effectives, that is, only those who had attended drills, could compete. With the rifle range near the hotel, these bisleys became social highlights and in the afternoon excited spectators followed the progress of the marks- 
men. Shooting commenced at 700 yards, then 500,300 and 200 , with five shots per man at each range. Ties were to be decided by attendance at drill; no guns were to be cleaned during firing; the Hythe position was compulsory and maximum pull on the trigger had to be three pounds. Needless to relate, but the day's proceedings were concluded with a sumptuous dinner at the hotel. As from December 1863, the annual subscription was lowered, and in 1865 new members were exempt from payment for the first six months, while manoeuvres, were enjoyed by the men.

By 1866 the severe economic depression which had engulfed the Cape Colony, caused the Volunteer Movement to go into recess for about ten years.

\section{The second period [1876-1882]}

The second period of the Volunteer movement commenced in 1876, when the Colonists, faced with hostilities which eventually flared up in 1878/79 in Basutoland, Griqualand, Pondoland and Zululand, prepared for emergencies. Immediately the "Midland Mounted Rifle Volunteer Corps" and the "Graaff Reinet Rifle Volunteer Corps" were established. In November 1876, Captain G. G. Munnik [later Acting-Magistrate] proposed that the district be sub-divided into four areas: Graaff Reinet town: Wheatlands, Bloemhof and Camdeboo, that instructors should visit all areas and that every month, all troops should assemble in Graaff Reinet. A new uniform was also accepted. ${ }^{2}$

In January 1878 A. H. le Roux was appointed Commandant of all the G. R. forces, it being estimated that there were approx. 1111 white and 448 coloured men liable for burgher duty. Rates of pay varied from that of 15/- per day for a Captain to $3 /$ - for a private, and when in the field, the rates and allowances were increased in proportion. A company of about 100 men was entitled to a Captain, and for every twenty-five men, a sergeant and a corporal could be appointed.

It is almost tragic to relate, "but the wholesome commandeering of men, horses etc., has ended in a complete farce, which casts discredit on the district." Thus wrote the "Graaff Reinet Herald" in January 1878. Le Roux's instructions were to ballot 250 men, but after the first call, only fiftesn answered:
In addition, the town was suddenly harassed by bogus notices signed by the "Magistrate" and "Field Cornet", commandeering men and supplies, which enveloped the town into complete chaos.

In fact, there were many reasons why the young men, instead of being aroused "to arm", were instead aroused "in anger." Foremost among the reasons during 1880 and 1881, was the so-called "Unequal Burgher Law" and their complaints were briefly: that despite the State call for 3000 men aged 18-30, the lists were in such a muddle, that a large number of men over thirty were called out; they resented the number of men exempted, implying that those who drew up the lists, served their friends well; that magistrates took upon themselves wider powers than were necessary in cases of minor infringements of the law by would-be-Volunteers; that M.P.'s and civil servants, who earned high salaries, were exempt from military duty; they resented the Continentalconscription systems and regarded as "legalised robbery" the fact that the older men could sit at home and grow richer and richer, without contributing a penny to the selfdefence of the Colony.

The rich [Volunteer] could engage substitutes which cost them anything from £25 to $£ 100$, but unfortunately, as these were men from the coastal towns, they were adventurers, untrained for riding and shooting and liable to breaches of discipline and insubordination in the field.

The "Graaff Reinet Herald" supported the claims of the Volunteers and remarked that "The Defence System of the present Ministry has utterly broken down." This opposition to compulsory burgher service was an unexpected development in an otherwise peaceful community and stemmed largely from historical reasons.

Of all the communities in the Cape Colony, the Graaff Reinetter had the strongest tradition of the commando system in his veins. The older Afrikaners had willingly responded to follow leaders like Stockenström and among the first generation of English settlers, they had witnessed the devastation of the 6th Frontier War . . . . but to their grandsons and sons they had passed on their resentment against injustice.

The young men were willing enough to respond to the call of their country, but they 
desired a general call up of all citizens. Now perhaps for the first time since the British Occupation of the Cape in 1806, the colonist began to dispute Government legislation. The time-honoured commando system was no more, but also, now the Colonist was no longer fighting for survival, but participating in the wars of the British Empire, which did not directly concern him.

Another cause for dissatisfaction, was the fact that neither horses, arms nor clothes were supplied by the State when the call-up came. This delay was unfortunate. Others complained about the inadequate outfit which consisted of:

One rifle and complete accoutrements, one suit clothes, one pair of boots, two pairs of socks, two shirts, one blanket, one grey coat, one hat, one knife, fork and spoon, one canteen and water bottle and one haversack. In fact, when in the field, Captain P. G. Maynier's men of C Troop, sent an S.O.S. for more trousers !

Fortunately good sense prevailed on the part of the authorities as well as the Volunteers and it was, significantly, the Volunteer farmers who rallied first to the call. In 1879 Captain Wright was gazetted and was busy drilling troops in the Town Hall yard. Meanwhile contingents came and went. Perhaps one of the most impressive send-offs was that of the contingents under Capt. H. Minnaar and Capt. H. Marriott, when the local brass band added colour to the festivities. Before their departure, a service was conducted by the Revs. Steabler, Philip and Brigg. Each group was presented with a flag: Miss Thornton had prepared a red flag on which stood a broad white cross and the motto "Where duty calls, there we will go" for Capt. Marriott, and Miss Olivier made a flag for Capt. Minnaar with the motto "Eendragt maak magt." From Murraysburg came a contingent under Capt. Sissison, while in January 1878, the two earliest detachments, under Capts. Bland and Walter Murray departed.

Walter Murray's group who called themselves the "Voor Sneeuberg Rangers" had an interesting history. Four years after Professor Gill's bisleys were discontinued, the local men showed great enthusiasm for reviving this type of sport, and by 1870 , Rifle Clubs became very popular, the two main ones being the "G.R. Rifle Club" and the "Voor Sneeuwberg Rifle Club." The latter met regulariy at the Goliad's Kraal Hotel and was composed mostly of local farm lads who soon came to regard their best marksman Walter Murray, as their natural leader. On the 28th January 1878, the "Rangers" assembled on the farm of Piet Loots, where the farmer's wife, assisted by several ladies, not only provided refreshments, but placed a rosette on each Volunteer's breast. Mrs. Hudson, the wife of the Magistrate, prepared a special silk flag for them, with the colours red, white and blue, with the motto "For Queen and Country" embroidered thereon. The Volunteers were sworn in by Mr. Watermeyer, which was followed by an address and prayer by the Rev. Leibrandt. Of the eleven townsmen in the contingent, one was found to be short of a horse, and within seconds, he had several offers. With three cheers for the hospitable host, the Volunteers rode off. An interesting fact is that in those days, letters to Volunteers in the field were sent free. Three days later, Murray in a letter to his wife, wrote that at Cradock" We had a warm reception here, a brass band played us into town."

In keeping with South African traditions, the return of the Volunteers was the scene of great festivities. During the years of hostilities, the citizens at home started a "War Relief Fund", for the sufferers and dependants of those killed on active service while the day following their return, was celebrated quietly as a day of prayer and thanksgiving. The 3rd Cape Yeomanry consisted of five troops: A-Uitenhage; B-Humansdorp; CGraaff Reinet; D-Somerset East and EThornhill. In the campaign, the Graaff Reinetters acquitted themselves with distinction. In the Battle of Thomas Piver, Capt. Murray e.g. is reported to have shot with great coolness, while on horseback, five enemies and then stopped to cool his gun. The Graaff Reinetters saw action at Mohalieshoek, Mafeteng, Kalabani and the famous battle of Morosi, where twelve men were killed, including four from Graaff Reinet. The memorial to these Volunteers stands in the Magennis Park, Uitenhage.

Extract from: C. G. Henning: A Cultural History of Graaff Reinet 1786-1886. D. Phil. Thesis, University of Pretoria, 1971.3 
NOTES:

\section{Author's emphasis.}

2. 1860 Uniform: a shell jacket of Russel cord, red facings, dark trousers with black braid down the outward seams; white trousers in summer, and a Black cap with a French peak; in winter a black jacket and white trousers was worn at all parades.

1863 Uniform: a grey tunic and trousers; facings, green edged with red; headdress, a felt-helmet with steel spike, or a demi-shako; also a brown leather knee-cap, for kneeling while shooting. Cost of Uniform: £3-15

1878 Uniform: Cavalry: coat of serge blue, [cut as military officers' patrol jackets], bound with black braid, with braid shoulder knots, trousers of drab Bedford strapped; Jack boots, a spiked helmet and a black cap with peak and puggaree, a finally, a buff leather belt and pouch as well as a bucket for the carbine; Infantry:- a grey cloth tunic and trousers, with black facings, spiked helmet with grey cap and peak with puggaree, with a buff leather belt and one pouch.

3. Reprinted with kind permission by the author.

\section{Boekbesprekíngs' Book reviews}

ROLF GüTH: Die Marine des Deutschen Reiches 1919-1939, Bernard \& Craefe Verlag für Wohrwesen, Frankfurt am Main [1972], pp. 263. Prys: DM 20,-.

In hierdie publikasie is beskryf op watter wyse die Duitse Ryksmarine [Reichsmarine] wat op 1.1.1921 gestig is en vanaf 21.5.1935 as die Duitse Krygsmarine [Kriegsmarine] bekendgestaan het, feitlik binne 'n tydperk van twintig jaar tot 'n weermagsdeel uitgegroei het wat deur sy slaggereedheid die verbasing en verwondering van die toenmalige eersterangse seevarende moondhede verwek het. Voordat daar kortliks op hierdie ontwikkelingsgang ingegaan word, is dit van belang om die skrywer se gebruik van die woord en begrip marine, in teenstelling met vloot, te verduidelik. Kapt. Güth lê, in hierdie verband, die nadruk op die volgende: Volgens sy sienswyse bestaan die seestrydkragte van 'n land uit die volgende komponente: Die vloot, die ondersteunings-en hulpvaartuie en die onderskeie inrigtings en verdedigingswerke op land. Dit, aldus dieselfde skrywer, in teenstelling met die Britse gebruik van die woord en begrip navy, terwyl hy andersyds opmerk dat die Franse en Duitse woordgebruik en begripsinhoud ooreenkom [p.16].

Gedurende die tydperk 1919-1939 het, behalwe waar dit die reeds genoemde naamsverandering betref, die Duitse marine 'n groot aantal uiteenlopende veranderings op verskillende gebiede ondergaan.

Dit is interessant om te weet dat tot 31.12. 1921 dié vlootvaartuie wat kragtens die verdrag van Versailles in Duitse besit gebly het, onder die eertydse keiserlike oorlogsvlag gevaar het. In 1921 is 'n nuwe oorlogsvlag deur Rykspresident Friedrich Ebert ingestel wat uit swart-wit-rooi bane, met in die middel 'n Ysterkruis, bestaan het. Tewens is die kleure van die Weimarrepubliek, swart-rooigoud, in die geus gevoer. In 1933 het die geus verval en in 1935 het die nuwe Ryksmarine se oorlogsvlag, met as sentrale kenteken die hakekruis, en met die Ysterkruis in die geus, sy verskyning gemaak.

Organisatories beskou, is die oudste bepalings in dié verband sowel in die verdedigingswet van 21.3.1921 as in die Duitse grondwet van 18.6.1921 neergelê. Van 19191920 het die sentrale gesagvoering van die Duitse marine bekendgestaan as die Admiralite:t [D.: Admiralität], van 1.10.192021.5.1935 as die Marineleiding [D.: Marineleitung] en daarna as die Opperkommando van die Krygsmarine [D.: Oberkommando der Kriegsmarine].

Wat die leser van hierdie studie veral tref, is die feit dat die Duitse marine, net soos die Duitse leër, sterk onderhewig was aan binneen buitelandse aangeleenthede en koersveranderings en dat die funksie van die marine uiters gevoelig ten opsigte van buitelandse invloede en internasicnale magverhoudings was.

In hierdie opsig moet daar allereers melding gemaak word van binnelandse beroerings kort voor en na die ineenstorting van die Duitse keiserryk en na die magsoorname deur Hitler, die knellende bande van die militêre bepalings van die verdrag van Versailles [1919], die vlootkonferensies van Washington [1921, 1927] die toetreding van Duitsland tot die Volkebond [1926], die einde van die internasionale militêre beheer oor Duitsland, die vloot- en ontwapeningskonferensies [1930-1933], die uittreding van Duitsland uit die Volkebond [1933], die toenaderingsbeleid tot Engeland en die Duitse besluit om, deur 